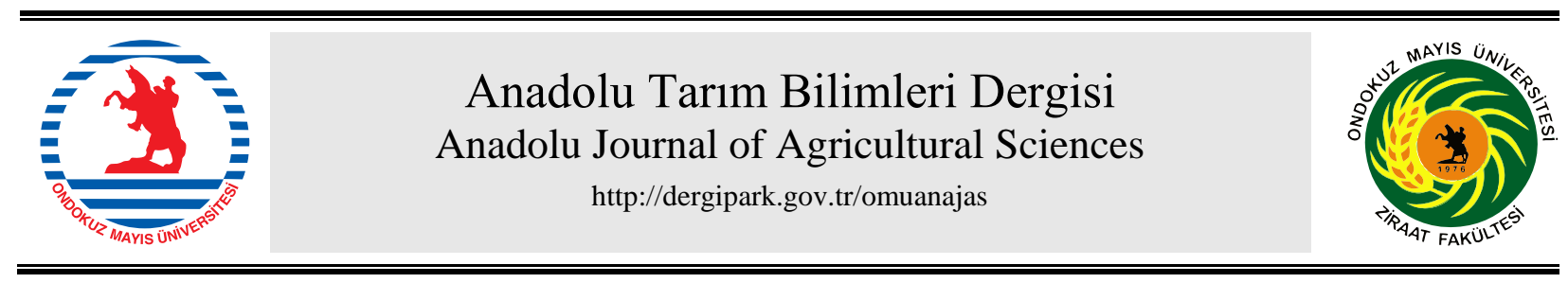

Araştırma/Research

Anadolu Tarım Bilim. Derg./Anadolu J Agr Sci, 36 (2021)

ISSN: 1308-8750 (Print) 1308-8769 (Online)

doi: 10.7161/omuanajas.902843

\title{
Şeker mısırında farklı organik materyal ve azot uygulamalarının koçan verimi ve bazı agronomik özellikler üzerine etkisi
}

\author{
๑İlknur Akgün ${ }^{\mathrm{a}^{*}}$, ๑Ruziye Karaman ${ }^{\mathrm{a}^{*}}, \oplus$ Aykut Şener ${ }^{\mathrm{a}}$ \\ ${ }^{a}$ Isparta Uygulamalı Bilimler Üniversitesi, Ziraat Fakültesi, Tarla Bitkileri Bölümü, Isparta, Türkiye
}

*Sorumlu yazar/corresponding author: ruziyekaraman @isparta.edu.tr

Geliş/Received 28/03/2021 Kabul/Accepted 09/09/2021

\begin{abstract}
ÖZET
Araştırmada geleneksel gübre uygulaması (10 ve $\left.20 \mathrm{~kg} \mathrm{~N} \mathrm{da}^{-1}\right)$ ile farklı organik materyal [azot ilaveli ve ilavesiz gül posası ile deniz yosunu (Ascophyllum nodosum), farklı zamanda gül posası uygulaması] uygulamalarının Vega F1 şeker mısır çeşidinde koçan verimi ve bazı tarımsal özelliklere etkisi belirlenmiştir. Araştırma tesadüf blokları deneme desenine göre 3 tekerrürlü olarak kurulmuş ve kontrol ile birlikte toplam 9 farklı uygulama yer almıştır. İki yıllık ortalama verilere göre, uygulamaların tamamında kardeş sayısı, bitki boyu, ilk koçan yüksekliği, koçan sayısı, koçan çapı, koçan randımanı ile pazarlanabilir kavuzlu ve kavuzsuz koçan veriminde kontrole göre istatistiksel olarak önemli seviyede artış belirlenmiştir. Vega F1 şeker mısır çeşidinde farklı şekilde gül posası ile deniz yosunu uygulamaları, bitki gelişmesine olumlu katkı sağlamasına rağmen, en yüksek kavuzlu ve kavuzsuz koçan verimi $20 \mathrm{~kg} \mathrm{da}^{-1} \mathrm{~N}$ uygulamasından elde edilmiştir. Koçan sayısı, koçan çapı, koçan randımanı ve kavuzlu koçan ağırlığı yönünden 10 ve $20 \mathrm{~kg} \mathrm{da}^{-1} \mathrm{~N}$ uygulamaları arasında önemli bir farklılık bulunmamıştır. Kardeş sayısı, bitki boyu ve ilk koçan yüksekliğine ait değerler, uygulamalara göre istatistiksel olarak farklılık göstermemiş ve kontrol hariç aynı grupta yer almıştır.

Sonuç olarak, Vega F1 şeker mısırında yüksek verim için deniz yosunu ve gül posası uygulamalarına ilave azotun verilmesi gerektiği ortaya konulmuştur.
\end{abstract}

Effects of different organic material and nitrogen applications on ear yield and some agronomic characters of sugar corn

\section{ABSTRACT}

In the research, effect of traditional fertilizer application (10 and $20 \mathrm{~kg} \mathrm{~N} \mathrm{da)} \mathrm{and} \mathrm{different} \mathrm{organic}$ material [application of nitrogen addition and without addition, rose pulp with seaweed (Ascophyllum nodosum) and rose pulp at different periods] applications was determined on ear yield and some agricultural properties in Vega F1 sweet corn variety. The study was carry out according to completely randomized blocks trial design with 3 repetitions and a total of 9 different applications were included with the control in study. According to two- years average data, statistically significant increase was determined to the control in number of tiller, plant height, first ear height, ear number, ear diameter, husk yield (husk ratio), marketable yield of husked and huskless ear. Although differently applications of rose pulp and seaweed in Vega F1 sweet corn variety positively contributed to plant growth, the highest husk and huskless ear yield was obtained from $20 \mathrm{~kg} \mathrm{da}^{-1} \mathrm{~N}$ application. No significant difference was found between 10 and $20 \mathrm{~kg} \mathrm{da}^{-1} \mathrm{~N}$ applications in terms of the ear number, ear diameter, ear performance and husked weight. The values related to tiller number, plant height and first ear height didn't differ statistically according to the applications and in the same group except control.

As a result, it was revealed that additional nitrogen should be given to seaweed and rose pulp applications for high yield.
Anahtar Sözcükler:

Şeker misır Koçan özellikleri Gül posası Deniz yosunu Azotlu gübreleme
Keywords: Sweet corn Ear properties Rose pulp Seaweed Nitrogenous fertilization

(C) OMU ANAJAS 2021 


\section{Giriş}

Şeker mısırı yeni dünya orjinli olup (Welbaum, 2015) mısırın alt türlerinden (at dişi mısır, sert mısır, cin mısır, şeker mısır, kavuzlu mısır, unlu mısır ve mumlu mısır) birisidir. Tatlı mısırın orjini hakkında kesin bilgi bulunmamakla birlikte, Peruluların "Chuspillo veya "Chullpi" olarak isimlendirdikleri mısır çeşidinden mutasyonla oluştuğu ileri sürülmektedir. Şeker mısırı varyetelerinde tane rengi (sarı, beyaz veya iki renkli ), olgunlaşma zamanı (erkenci, orta geççi ve geçç) ve şeker içeriği yönünden [standart (su-1), şeker içeriği artırılmış (se), süper tatlı (sh2)] farklı çeşitler bulunmaktadır. Şeker mısırı tanesinde suda çözülebilir protein içeriği diğer mısır türlerinden daha fazladır. Hasat olgunluğuna gelen tatlı mısırda \% 5-6 şeker, \% 10-11 nişasta, \% 3 suda çözülebilir polisakkaritler, \% 70 su, \%15 protein, \%9 yağ, vitamin A ve potasyum, yüksek miktarda fosfor, magnezyum, demir ve çinko bulunduğu bildirilmiştir (Dickerson, 1996; Keerthi ve ark., 2017; Sevov, 2017). Şeker mısırı üretiminde lider ülkelerin başında USA gelmekte, bunu, Nijerya, Meksika, Endonezya, Peru takip etmektedir (FAO, 2020). Ülkemizde şeker mısırının ekim alanı ve üretim miktarı ile ilgili istatistiksel kayıtlar tespit edilememiştir. Türkiye'de şeker mısırı ekim alanı, toplam mısır ekim alanının \%1-2'si kadar olduğu tahmin edilmektedir (Arslan ve Williams, 2015).

Birim alandan maksimum verimin elde edilmesinde en büyük girdiyi kimyasal gübreler oluşturmaktadır. Misır üzerinde yapılan araştırmalarda verimi etkileyen en önemli faktörler arasında bitki sıklı̆̆ı, gübreleme ve yetiştirme tekniklerinin olduğu bildirilmektedir (Giskin ve Etran, 1986) Yapılan çalışmalar incelendiğinde mısır bitkisi en yüksek verimine $20-30 \mathrm{~kg} \mathrm{~N} \mathrm{da}^{-1}$ dozunda ulaşıldığı görülmektedir. Tek taraflı ve fazla miktarda ticari gübrenin kullanılması ile toprakların fakirleşmesi, fiziksel özelliklerinin bozulması yanı sıra bitki besin elementlerinin alımı da olumsuz yönde etkilenmektedir. $\mathrm{Bu}$ nedenle gübre kullanımını azaltacak farklı uygulamalara ihtiyaç duyulmaktadır.

Bitkisel atıklar veya tarımsal endüstri atıklarının tarımda başarılı bir şekilde kullanılabileceği yapılan pek çok çalışma ile belirlenmiştir. Bitkisel kökenli atıklar ciddi bir organik madde kaynağı olmanın ötesinde içermiş oldukları bazı bitki besin maddeleri yönünden de önemli bir potansiyele sahiptirler. Bu materyallerin geri kazanımı ile hem organik madde içeriği düşük olan topraklarımızın organik madde içeriği artırılmış, hem de daha az kimyasal gübre kullanımına olanak sağlayabilir.

Türkiye en önemli gül yă̆ üretici ülkelerden birisi olup, 2019 yılı verilerine göre dikim alanı 38454 dekar ve yağlık gül üretimi ise 16.6 bin tondur. Bu üretimin \% 85.12'si Isparta ilinde yapılmakta (FAO, 2020) ve yılda yaklaşık 30 bin ton kadar posa elde edilmektedir (Baydar ve ark., 2020). Gül posasının bitki gelişimini olumlu yönde etkilediği için, tarımsal amaçlı doğrudan veya zenginleştirilerek kullanılabileceği bildirilmiştir (Erdal ve Aydemir, 2003). Araştırmalar sonucunda, gül posasının ortalama besin içeriğinin organik madde \% 84.2; toplam azot \%3.7; toplam fosfor $1.99 \mathrm{mg}$ g; toplam potasyum $24 \mathrm{mg} \mathrm{g}$ ve magnezyum $5 \mathrm{mg}$ g olduğunu bildirmişlerdir (Tosun ve ark., 2003). Gül posasının oldukça kaliteli ve ekonomik bir organik gübre kaynağı olduğunu, Sn, Ni ile $\mathrm{Pb}$ gibi ağır metallerin miktarlarının kabul edilebilir üst sınır değerlerinin altında kaldığını ve gül posasının organik gübre olarak kullanıldığında insan ve çevre sağlığı için bir risk taşımadığı ileri sürülmüştür (Baydar ve ark., 2020).

Deniz yosunu ekstraktlarının tarımsal amaçlı kullanılması ile çimlenmenin arttığı, yaprakların daha büyük olduğu, kök gelişmesini teşvik ettiği, olumsuz toprak koşullarına karşı dayanımı arttırdığı ve topraktaki besin elementlerinin alımını teşvik ettiği ileri sürülmüştür (Hong ve ark., 1995). Deniz yosunlarında birçok çeşit bulunmakta olup, bu çeşitlerin arasından tarımda en yaygın olarak kullanılanı Ascophyllum nodusum (L.) olduğu bildirilmiştir. Ayrıca, Fucus spp., Laminaria spp., Sargassum spp. ve Turbinarina spp. türleri de Ascophyllum nodusum (L.) gibi doğal gübre olarak kullanılmaktadır (Hong ve ark. 2007).

$\mathrm{Bu}$ çalışmada, kimyasal gübre kullanımının azaltılması ve doğal materyallerin kullanılmasının arttırılması, tarımsal atıkların üretime yeniden kazandırılması amaçlanmıştır. Araştırmada farklı dozlarda azot, deniz yosunu ve gül posası uygulamasının şeker mısırında (Zea mays saccarata) koçan verimi ve bazı tarımsal özellikler üzerine etkisi belirlenmiştir.

\section{Materyal ve Yöntem}

Araştırma, Ziraat Fakültesi Eğitim, Araştırma ve Uygulama Çiftliği arazisinde 2015 ve 2016 yıllarında yürütülmüştür. Çalışmada geleneksel gübre uygulaması (10 ve $\left.20 \mathrm{~kg} \mathrm{~N} \mathrm{da}^{-1}\right)$ ile farklı organik materyal (gül posası ve deniz yosunu (Ascophyllum nodosum) uygulamalarının, şeker mısırının koçan verimi ve bazı tarımsal özellikleri üzerine etkileri karşılaştırılmıştır. Denemede Vega $F_{1}$ şeker mısır çeşidi, azot kaynağı olarak Nitropower33 (\%33 N), fosfor kaynağı olarak ise, Triple Süper Fosfat (TSP) gübreleri kullanılmıştır. Araştırma tesadüf blokları deneme desenine göre 3 tekerrürlü olarak kurulmuştur. Her parselde 9 farklı uygulama yer almış ve bu uygulamalar aşağıda verilmiştir.

a) Kontrol: Ekimle birlikte $10 \mathrm{~kg} \mathrm{da}^{-1} \mathrm{P}_{2} \mathrm{O}_{5}$ uygulanmıştır. 
b) Deniz yosunu (Ascophyllum nodosum) uygulaması: Ekimle birlikte $10 \mathrm{~kg} \mathrm{da}^{-1} \mathrm{P}_{2} \mathrm{O}_{5}+$ toprağa katı toz şeklinde $500 \mathrm{~g} \mathrm{da}^{-1}$ deniz yosunu uygulanmıştır.

c) Azotlu gübre ilave edilmiş deniz yosunu uygulaması: Ekimle birlikte $10 \mathrm{~kg} \mathrm{da}^{-1} \mathrm{P}_{2} \mathrm{O}_{5}+$ toprağa toz şeklinde $500 \mathrm{~g} \mathrm{da}^{-1}$ deniz yosunu $+5 \mathrm{~kg} \mathrm{da}^{-1} \mathrm{~N}$ uygulanmıştır.

d) Katı ve sivı halde deniz yosunu (Ascophyllum nodosum) uygulaması: Ekimle birlikte $10 \mathrm{~kg} \mathrm{da}^{-1} \mathrm{P}_{2} \mathrm{O}_{5}+$ toprağa toz şeklinde $500 \mathrm{~g} \mathrm{da}^{-1}$ deniz yosunu + sıvı halde $500 \mathrm{~g} \mathrm{da}^{-1}$ olacak şekilde yaprak gübrelemesi. Sıvı yaprak gübresi bitkiler yaklaşı $30-40 \mathrm{~cm}$ bitki boyuna ulaştığı zaman sırt pülverizatörü ile uygulanmıştır.

e) Ekimden önce gül posası uygulaması: Ekimle birlikte $10 \mathrm{~kg} \mathrm{da}^{-1} \mathrm{P}_{2} \mathrm{O}_{5}+$ ekimden 40-45 gün önce dekara 4 ton hesabiyla parsellere uygulanmıştır.

f) Ekimle birlikte gül posası uygulaması: Ekimle birlikte $10 \mathrm{~kg} \mathrm{da}^{-1} \mathrm{P}_{2} \mathrm{O}_{5}+$ ekimle birlikte 4 ton $\mathrm{da}^{-1}$ gül posası parsellere uygulanmıştır.

g) Azotlu gübre ile ilave edilmiş gül posası uygulaması: Ekimle birlikte $10 \mathrm{~kg} \mathrm{da}^{-1} \mathrm{P}_{2} \mathrm{O}_{5}+4$ ton $\mathrm{da}^{-1}$ gül posası + $5 \mathrm{~kg} \mathrm{da}^{-1} \mathrm{~N}$ gübrelemesi yapılmıştır.

h) $10 \mathrm{~kg} \mathrm{da}^{-1} \mathrm{~N}$ uygulaması: Ekimle birlikte $10 \mathrm{~kg} \mathrm{da}^{-1} \mathrm{P}_{2} \mathrm{O}_{5}+10 \mathrm{~kg} \mathrm{da}^{-1} \mathrm{~N}$ gübrelemesi yapılmıştır.

i) $20 \mathrm{~kg} \mathrm{da}^{-1} \mathrm{~N}$ uygulaması: Ekimle birlikte $10 \mathrm{~kg} \mathrm{da}^{-1} \mathrm{P}_{2} \mathrm{O}_{5}+20 \mathrm{~kg} \mathrm{da}^{-1} \mathrm{~N}$ gübrelemesi yapılmıştır.

Tohumlar markörle çizilen sıralara sıra arası $70 \mathrm{~cm}$, sıra üzeri $20 \mathrm{~cm}$ olan mesafelerde elle açılan ocaklara mayıs ayının ilk haftasında (Akgün ve ark., 2017) ekilmiştir. Her ocağa 2 tohum atılmış, çimlenme tamamlandıktan sonra her ocakta 1 bitki bırakılmıştır. Uygulanacak azotlu gübre dozlarının yarısı ve $10 \mathrm{~kg}$ fosfor $\left(\mathrm{P}_{2} \mathrm{O}_{5}\right)$ ekimle beraber, azotun diğer yarısı ise boğaz doldurma işlemi ile birlikte (bitkiler 30-40 cm ulaşınca), elle serpme olarak verilmiştir. Araştırmada bir yıl bekletilmiş ve yanmış özellikte olan gül posası, dekara 4 ton olacak şekilde parsel alanına göre hesaplanarak, toprak yüzeyine serilerek çapa motoruyla toprağa karıştırılmıştır. Sulama, damla sulama şeklinde ekimden itibaren bitkinin nem stresine girmesini önleyecek şekilde uygulanmıştır. Bitkiler süt olum döneminde (koçan püskülleri kurumuş ve tanelere tırnak ile bastırıldığında tanelerden sıvı çıktığı dönem) başlardan $0.5 \mathrm{~m}$, kenarlardan birer sıra kenar tesiri olarak atıldıktan sonra kalan 2 sıradaki bitkilerin taze koçanlar elle hasat edilmiştir. Her parselde tesadüfen seçilen 10 adet bitkide; kardeş sayısı (adet), bitki boyu (cm), ilk koçan yüksekliği $(\mathrm{cm})$, koçan çapı $(\mathrm{mm})$, bitki başına koçan sayısı (adet), koçan randımanı (\%), pazarlanabilir kavuzlu ve kavuzsuz koçan verimine $\left(\mathrm{kg} \mathrm{da}^{-1}\right)$ ölçüm ve tartımlar yapılmıştır (USDA, 1992; Anonim, 2010). Araştırmada koçan verimi pazarlanabilir (kavuzları soyulduktan sonra koçan uzunluğu $10.2 \mathrm{~cm}$ den daha uzun ve ağırlı̆̆ $250 \mathrm{~g}$ üzerinde olanlar dikkate alınmıştır) koçan sayısı üzerinden dekara verim hesaplanmıştır.

Deneme alanın 0-30 cm derinlikten alınan toprağın analiz sonuçları; tınlı yapıda, $\mathrm{pH} 7.9$, Kireç $\left(\mathrm{CaCO}_{3}\right)$ içeriği $\%$ 29.48, toplam tuz içeriği $0.014 \mathrm{dS} \mathrm{m}^{-1}$, fosfor $\left(\mathrm{P}_{2} \mathrm{O}_{5}\right) 7.20 \mathrm{~kg} \mathrm{da}^{-1}$, potasyum $\left(\mathrm{K}_{2} \mathrm{O}\right) 176.24 \mathrm{~kg} \mathrm{da}^{-1}$ ve organik madde \% 0.84 olarak belirlenmiştir.

Çizelge 1. Isparta ilinde araştırmanın yürütüldüğg̈ yıllar ve uzun yıllara (1950-2014) ait iklim verileri*

Table 1. Climate datas as to conducted years of research and long years (1950-2014) in Isparta province*

\begin{tabular}{|c|c|c|c|c|c|c|c|c|c|}
\hline \multicolumn{10}{|c|}{ İklim Faktörleri/ Climate Factors } \\
\hline \multirow{3}{*}{$\begin{array}{l}\text { Y1llar/ } \\
\text { Aylar } \\
\text { Years/ } \\
\text { Months }\end{array}$} & \multirow{2}{*}{\multicolumn{3}{|c|}{$\begin{array}{l}\text { Ortalama Sicaklık }\left({ }^{\circ} \mathrm{C}\right) \\
\text { Mean Temperature }\left({ }^{\circ} \mathrm{C}\right)\end{array}$}} & \multirow{2}{*}{\multicolumn{3}{|c|}{$\begin{array}{l}\text { Toplam Yağış }(\mathrm{mm}) \\
\text { Total Precipitation }(\mathrm{mm})\end{array}$}} & \multirow{2}{*}{\multicolumn{3}{|c|}{$\begin{array}{l}\text { Ortalama Nispi Nem (\%) } \\
\text { Mean Relative Humidity (\%) }\end{array}$}} \\
\hline & & & & & & & & & \\
\hline & $\begin{array}{l}\text { Uzun y1llar/ } \\
\text { Long years }\end{array}$ & 2015 & 2016 & $\begin{array}{l}\text { Uzun yillar/ } \\
\text { Long years }\end{array}$ & 2015 & 2016 & $\begin{array}{l}\text { Uzun yillar/ } \\
\text { Long years }\end{array}$ & 2015 & 2016 \\
\hline $\begin{array}{l}\text { Nisan } \\
\text { April }\end{array}$ & 10.8 & 8.7 & 13.8 & 53.1 & 26.1 & 47.8 & 61.3 & 60.7 & 52.1 \\
\hline $\begin{array}{l}\text { Mayıs } \\
\text { May }\end{array}$ & 15.5 & 16.1 & 14.5 & 54.3 & 67.5 & 87.6 & 57.4 & 59.8 & 64.4 \\
\hline $\begin{array}{l}\text { Haziran } \\
\text { June }\end{array}$ & 20.1 & 17.8 & 21.6 & 31.5 & 92.2 & 12.7 & 51.2 & 67.7 & 47.7 \\
\hline $\begin{array}{l}\text { Temmuz } \\
\text { July }\end{array}$ & 23.5 & 23.7 & 24.8 & 14.5 & 3.0 & 25.7 & 45.4 & 48.3 & 44.9 \\
\hline $\begin{array}{l}\text { Ağustos } \\
\text { August }\end{array}$ & 23.2 & 23.5 & 24.5 & 10.7 & 43.4 & 45.4 & 46.4 & 54.8 & 51.8 \\
\hline $\begin{array}{l}\text { Ort/Top } \\
\text { Mean/total }\end{array}$ & 18.6 & 18.0 & 19.8 & 164.1 & 232.2 & 219.2 & 52.3 & 58.3 & 52.2 \\
\hline
\end{tabular}

*:Kaynak:Meteoroloji Genel Müdürlüğü

Denemenin yürütüldüğü yıllara ve aylara ait iklim verileri Çizelge 1'de verilmiştir. Vejetasyon dönemindeki uzun yıllar sıcaklık ortalaması $\left(18.6^{\circ} \mathrm{C}\right), 2016\left(19.8^{\circ} \mathrm{C}\right)$ yılına ait sıcaklık ortalamalarından daha düşük, 2015 $\left(18.0^{\circ} \mathrm{C}\right)$ yılından ise daha yüksek bulunmuştur. Denemenin 2. yılı daha sıcak geçmiştir. İlk yıl vejetasyon dönemi boyunca alınan toplam yağış miktarı $(232.2 \mathrm{~mm})$, uzun yıllar ortalamasından $(164.1 \mathrm{~mm})$ ve ikinci yıldan $(219.2$ 
$\mathrm{mm}$ ) daha fazla olarak gerçekleşmiştir. Nispi nem içeriğinin uzun yıllar ortalaması \% 52.3, 2015 yılının \% 58.2 ve 2016 yılının \% 52.2 olarak rapor edilmiştir.

Denemeden elde edilen verilerin değerlendirilmesinde, SAS (1998) paket programı kullanılmış ve tesadüf blokları deneme desenine göre varyans analizine tabi tutulmuştur. Ortalamalar arasındaki farklılıkların belirlenmesinde Duncan çoklu karşılaştırma testi kullanılmıştır.

\section{Bulgular ve Tartıșma}

\subsection{Kardeş sayısı ve Bitki boyu}

Vega F1 çeşidinin kardeş sayısı uygulamalara göre 1.7-2.2 adet arasında değişmiş ve bu farklılık istatistiksel olarak önemli bulunmuştur (Çizelge 2). Her iki yılda deniz yosunu uygulamasında en fazla kardeş sayısı elde edilmiştir. İki yıllık ortalama verilere göre, bu uygulama ile (kontrol hariç) diğer uygulamalar arasındaki farkın önemli olmadığı tespit edilmiştir. Araştırmanın yürütüldüğü yıllarda kardeş sayısı farklı olmuş ve 2. yıl kontrol ve deniz yosunu uygulaması hariç diğer uygulamalara göre kardeş sayısı daha fazla bulunmuştur. Genel ortalama olarak 1. yıl 1.9 adet, 2. yıl ise 2.1 adet olarak belirlenmiş ve bu farklılık istatistiksel olarak önemlidir. Araştırmada 2. yıl sıcaklık değerleri (Çizelge 1) birinci yıldan daha fazla olması kardeşlenmeyi teşvik etmiş olabilir. Akgün ve ark. (2017), tarafından yapılan çalışmada, Batem Tatlı çeşidinde yıllara bağlı olarak kardeş sayısında önemli farklılıklar belirlenmiştir (1. yıl: 1.95 adet, 2. yıl: 2.80 adet). Araştırıcılar, sıcaklık artışının kardeşlenmeyi teşvik ettiğini ileri sürmüşlerdir.

Şeker mısırı taze olarak tüketildiğinden kardeşlenme, hasattan sonra kalan yeşil bitkilerin farklı şekillerde (kaba yem veya silaj) değerlendirilmesinde önemlidir. Ancak kardeşlerde gelişen koçanların pazarlanabilirlik yönünden ticari bir değeri olmamasına rağmen, kaba yem üretimini arttırabilir. Şeker mısır üretiminde yan ürünlerin (pazarlanamayan koçanlar, saplar ve yapraklar) iyi bir hayvan yemi kaynağı olduğu ve süper tatlı hibrid çeşitlerin yeşil saplarında toplam şeker içeriği \% 20-22 ve protein oranı \% 8-9 arasında değiştiği bildirilmiştir (Sevov, 2017).

Kardeş sayısının genetik yapı ile ilgili olduğu ve çeşitlere göre değişebildiği ileri sürülmüştür (Walter-Shea ve ark.,1991). Genetik yapının yanında çevre şartları da etkilidir (Park ve ark., 1989). Ayrıca, birim alandaki bitki sıklığ1 (Park ve ark., 1989; Akgün ve ark., 2017) ve ekim zamanı kardeş sayısını etkileyebilmektedir (Akgün ve ark., 2017). Yine, azotlu gübrelemenin mısırda kardeş üretimini arttırdığı ileri sürülmüsşür (Park ve ark., 1989). Diğer taraftan kardeşlerin koparılması koçan boyunu azalttığı, (Park ve ark., 1989; Hanna ve Story, 1992) ve koçan püskülü çıkarma süresini kısalttığı bildirilmiştir (Sharma ve Adamu, 1984). Bu sonuçlar mısırda kardeş oluşumunun fotosentetik etkinliğe katkı sağladığını göstermektedir. Araştırmada organik madde (gül posası deniz yosunu) ve azotlu gübreleme kardeş sayısını önemli seviyede arttırmıştır.

İki yıllık ortalamalara göre bitki boyu 115.92-106.25 cm arasında değişmiş ve uygulamaların bitki boyuna etkisi önemli bulunmuştur. Organik madde ve azotlu gübre uygulaması bitki boyu üzerine olumlu etki yapmış ve kontrol uygulamasına göre bitki boyunu önemli seviyede arttırmışır. Araştırmada 2. yıl tüm uygulamalarda bitki boyu daha uzun olmuş ve bu farklılık istatistiksel olarak önemlidir (1. yıl: 105.89; 2. yıl: 119.97). Bu durum bitki boyu üzerine iklim ve toprak koşullarının etkili olduğunu göstermektedir. Denemenin ilk yılında dekar $10 \mathrm{~kg}$ ve $20 \mathrm{~kg}$ azot uygulamalarında yüksek değerler elde edilirken, 2. yıl azotlu gübre ile zenginleştirilmiş deniz yosunu ve ekimle birlikte gül posası uygulamasında daha yüksek değerler elde edilmiştir. Yıllara göre bitki boyunda en yüksek değerler, farklı uygulamalarda belirlenmiş olması yıl x uygulama interaksiyonunun önemli çıkmasına neden olmuştur (Çizelge 2).

Bitki boyundaki artış, yaprak alanını, dolayısıyla asimilasyon alanını da arttırmakta ve tane verimini de olumlu yönde etkilemektedir. Şeker mısırında bitki boyu, çeşide göre değiş̧ebildiği gibi iklim koşulları ve kültürel uygulamalar (ekim sıklığı, gübreleme, ekim zamanı gibi) da etkili olabilmektedir (Turgut ve Balc1, 2002; De Grazia ve ark., 2003; Öktem ve Öktem, 2006; Sönmez ve ark., 2013; Akgün ve Siyah, 2015). Bitki boyunun, araştırma yılına göre farklılık göstermesinde, hava sıcaklığının, nem ve yağışın etkili olduğu düşünülmektedir. De Grazia ve ark., (2003) şeker mısırında farklı dozlarda azot ve fosforlu gübre uygulamalarının bitki boyuna etkisi incelenmiştir. Araştırmada fosforun etkisi önemsiz bulunurken azot dozlarına bağlı olarak bitki boyu önemli seviyede artmış, ancak 10 ve $20 \mathrm{~kg} \mathrm{da}^{-1}$ uygulamaları arasındaki fark önemli bulunmamıştır.

Şeker mısırı çeşitlerinde sap kimyasal içeriği çeşitlere göre değiştiği belirlenmiştir (Sevov, 2017). Araştırıcı kuru madde içerisinde ham protein oranı \% 8.96-11.56, ham selüloz \% 22.55-23.96, ham kül \%04.30-4.57 ve toplam şeker içeriği \% 15.1-19.7 arasında değiştiğini tespit etmiştir. Vega F1 çeşidinde bu değerler sırasıyla \% 11.56, \% 23.85, \% 4.57 ve \% 18.2 olarak belirlenmiştir. Şeker misır üretiminde yan ürünlerin (pazarlanamayan koçanlar, saplar ve yapraklar) iyi bir hayvan yemi kaynağı olduğu ileri sürülmüştür.

Şeker mısırı erken dönemde hasat edildiğinden dolayı, geri kalan bitki kısımlar (taze yaprak, ticari değeri olmayan koçanlar ve saplar) kuru ya da taze olarak kaba yem kaynağı veya silajlık olarak değerlendirilebilir. Bu nedenle bitki boyunun uzun olması, daha fazla vegetatif aksam elde edilmesine katkı sağlayacaktır. Araştırmada 
geleneksel gübre uygulaması ile farklı organik madde uygulamaları arasında önemli bir farklılık belirlenmemiştir. Bu kullanılan organik maddelerin şeker mısırı gelişmesini olumlu yönde etkilediğini göstermektedir.

Çizelge 2. Şeker mısırında farklı uygulamaların kardeş sayısına (adet) ve bitki boyuna (cm) etkisi Table 2. Effect of different applications on number of tiller and plant height $(\mathrm{cm})$ in sweet corn

\begin{tabular}{|c|c|c|c|c|c|c|}
\hline \multirow[t]{2}{*}{ Uygulamalar/Applications } & \multicolumn{2}{|c|}{ Yillar/Years } & \multirow{2}{*}{$\begin{array}{l}\text { Ortalama/ } \\
\text { Mean }\end{array}$} & \multicolumn{2}{|c|}{ Yillar/Years } & \multirow{2}{*}{$\begin{array}{l}\text { Ortalama/ } \\
\text { Mean }\end{array}$} \\
\hline & 2015 & 2016 & & 2015 & 2016 & \\
\hline Kontrol /Control & 1.7 & 1.7 & $1.70 \mathrm{~B}^{1}$ & $97.67 \mathrm{e}^{1}$ & $114.83 c^{1}$ & $106.25 \mathrm{~B}^{1}$ \\
\hline Deniz yosunu /Seaweed & 2.2 & 2.2 & $2.20 \mathrm{~A}$ & $106.90 \mathrm{bc}$ & $118.47 \mathrm{~b}-\mathrm{d}$ & $112.68 \mathrm{~A}$ \\
\hline \multicolumn{7}{|l|}{ Fertizer with nitrogen + Seaweed } \\
\hline $\begin{array}{l}\text { Kat1 ve s1v1 deniz yosunu/ } \\
\text { Solid and liquit Seaweed }\end{array}$ & 1.9 & 2.0 & $1.95 \mathrm{AB}$ & $100.27 \mathrm{de}$ & $121.23 \mathrm{a}-\mathrm{c}$ & $\begin{array}{c}110.75 \\
\mathrm{AB}\end{array}$ \\
\hline \multicolumn{7}{|l|}{ Application of rose pulp in presowing } \\
\hline $\begin{array}{l}\text { Ekimle birlikte gül posas } \\
\text { Application of rose pulp with sowing }\end{array}$ & 1.9 & 2.3 & $2.10 \mathrm{AB}$ & $107.13 \mathrm{bc}$ & $123.57 \mathrm{ab}$ & $115.35 \mathrm{~A}$ \\
\hline \multicolumn{7}{|l|}{ Fertizer with nitrogen + Rose pulp } \\
\hline $\begin{array}{l}10 \mathrm{~kg} \mathrm{da}^{-1} \text { azotlu gübre/ } \\
10 \mathrm{~kg} \mathrm{da}^{-1} \text { Fertizer with nitrogen }\end{array}$ & 1.8 & 2.2 & $2.00 \mathrm{AB}$ & $112.80 \mathrm{a}$ & $119.03 \mathrm{~b}-\mathrm{d}$ & $115.92 \mathrm{~A}$ \\
\hline $\begin{array}{l}20 \mathrm{~kg} \mathrm{da}^{-1} \text { azotlu gübre/ } \\
20 \mathrm{~kg} \mathrm{da}^{-1} \text { Fertizer with nitrogen }\end{array}$ & 2.0 & 2.2 & $2.10 \mathrm{AB}$ & $112.17 \mathrm{ab}$ & $117.97 \mathrm{~cd}$ & $115.07 \mathrm{~A}$ \\
\hline \multirow[t]{2}{*}{ Ortalama/Mean } & $1.91 \mathrm{~B}^{1}$ & $2.10 \mathrm{~A}$ & & $105.89 \mathrm{~B}^{1}$ & $119.97 \mathrm{~A}$ & \\
\hline & \multicolumn{3}{|c|}{$\begin{array}{l}\text { Yll/Year:13.94**; } \\
\text { Uygulama/Application:2.588*; } \\
\text { YılxUygulama/YearxApplication:0.815; } \\
\text { CV:\%11.66 }\end{array}$} & \multicolumn{3}{|c|}{$\begin{array}{l}\text { Yll/Year:288.230**; } \\
\text { Uygulama/Application:5.862**; } \\
\text { YılxUygulama/YearxApplication: } 6.51 \\
\text { **; CV:\% } 2.7\end{array}$} \\
\hline
\end{tabular}

* \%5 ve ** \% 1 önemlidir. CV: Coefficient Variance ${ }^{1}$ Aynı sütunda ve aynı satırda farklı harfle verilen ortalamalar arasındaki fark önemlidir.

\subsection{Illk koçan yüksekliği ve Koçan sayısı}

Çalışmada ilk koçan yüksekliği 36.82-43.73 cm arasında değişmiştir. Azotlu gübre ile organik madde (gül posası ve deniz yosunu) uygulamaları arasında önemli bir farklılık belirlenememiş ve istatistiksel olarak aynı grupta yer almıştır. Ancak, kontrol uygulamasındaki ilk koçan yüksekliği, diğer uygulamalara göre önemli seviyede farklı bulunmuştur. Araştırmada ilk koçan 2. deneme yılında tüm uygulamalarda daha yüksekte oluşmuş (1. yıl: $41.12 \mathrm{~cm}$; 2. y1l: $43.02 \mathrm{~cm}$ ) ve yıllar arasındaki farkl1lık istatistiksel olarak önemlidir (Çizelge 3).

Mısır genellikle makine ile hasat edildiğinden ilk koçan yüksekliği önemli bir özelliktir. Araştırmada kontrol grubuna ait bitkilerde ve denemenin 1. yılında bitki boyuna ve (Çizelge 3) ilk koçan yüksekliğini ait değerler, daha düşük bulunmuştur. $\mathrm{Bu}$ durum bitki boyu ile ilk koçan yüksekliği arasında olumlu bir ilişkinin olduğunu göstermektedir. İlk koçan yüksekliğinin genetik yapının yanında, çevre koşullarından da etkilendiği farklı araştırmalarda belirlenmiştir. Nitekim, Stanslous ve ark. (2020), tarafında yapılan çalışmada çeşitlere göre ilk koçan yüksekliği 37.25-77.75 arasında değişmiştir. Bitki boyu uzun olan BATEM Tatlı ve Kompozit Şeker çeşitlerinde, ilk koçan yüksekliği de diğer çeşitlere göre daha uzun bulunmuştur. Yine, Öktem ve Öktem (2006), genelde bitki boyunun yüksek olduğu çeşitlerde, ilk koçan yüksekliğinin fazla, bitki boyunun düşük olduğu çeşitlerde ise ilk koçan yüksekliğinin daha az olduğunu bildirmiştir. Bu sonuçlar bizim araştırma sonuçlarını desteklemektedir.

Farklı çalışmalarda ilk koçan yüksekliğinin çeşide bağlı olarak Öktem ve Öktem (2006), 55.9-70.1 cm, İdikut ve Kara (2013), 53-77 cm arasında değiştiği bildirilmiştir. Diğer taraftan ilk koçan yüksekliği, bitki sıklığına, azot dozlarına, ekim tarihine ve diğer çevre faktörlerine göre de değişebilmektedir (Turgut, 2000; Turgut ve Balc1, 2002; Öktem ve Öktem, 2006; Özata ve ark., 2016).

Araştırmada iki yıllık ortalama incelendiğinde bitki başına koçan sayısı 1.23-2.0 adet arasında değişmiş ve uygulamalar arasındaki farklılık istatistik olarak önemli bulunmuştur. Dekara $10 \mathrm{~kg}$ ve $20 \mathrm{~kg}$ azot uygulamalarında bitki başına koçan sayısı 1.88 ve 2.0 adet arasında değişmiş ve bu farklılık istatistiksel olarak önemli değildir. Kontrol uygulamasına göre organik madde uygulamalarında bitki başına daha fazla koçan sayısı belirlenmiş olmakla birlikte, istatistiksel olarak aynı grupta yer almış ve aralarındaki farklılık önemli bulunmamıştır (Çizelge 3). Yıllara göre bitki başına koçan sayısı önemli seviyede değişiklik göstermiş ve 1. yıl 1.58 adet, 2. yıl ise 1.49 adet olarak belirlenmiştir. 
Eser (2014), tarafından yapılan çalışmada bitkide koçan sayısının çeşide göre değiştiği (1.06-1.46 adet) ve Vega F1 çeşidinde 1.20 adet/bitki olduğu belirlenmiştir. Araştırmada pazarlanabilir koçan verimi bakımından ise, en yüksek değer Vega F1 (1523.33 $\mathrm{kg} \mathrm{da}^{-1}$ ) çeşidinde tespit edilmiştir. Stansluos ve ark. (2020), 11 farklı şeker mısırı çeşidinde bitki başına koçan sayısı 0.98-1.28 adet arasında değiştiği ve çeşitler arasındaki farklılığın önemli olduğunu ortaya koymuştur. Yine, Sönmez ve ark. (2013), bitki başına koçan sayısının çeşitlere (1.56-1.96 adet/bitki) ve yıllara (1. y1l: 1.97; 2. y1l: 1.67 adet/bitki) göre önemli farklılık gösterdiğini bildirmişlerdir. Diğer taraftan Eşiyok ve ark. (2004), bitki başına koçan sayısının çeşitlere göre istatistiksel olarak önemli bir farklılık göstermediğini ve bitki başına koçan sayısını yaklaşık 1 adet olarak tespit etmişlerdir. Hibrit şeker mısırı çeşitlerinde genellikle tane verimi yüksek tek koçan, pazarlanabilir özelliktedir. Diğer koçanların birçoğunun ticari değeri düşüktür, ancak farklı şekillerde iyi bir hayvan yemi kaynă̆ını oluşturabilmektedir. Araştırmamızda kontrol uygulamasında Vega F1 çeşidinin bitki başına koçan sayısı 1.23 adet bulunmuştur. Ancak, farklı uygulamalara yıllara göre bitkideki koçan sayısı artmıştır. Yapılan araştırmaların birçoğunda benzer çeşitler kullanılmasına rağmen, elde edilen bitki başına koçan sayısını değişmiştir. Bu durum genetik yapının yanında çevre şartları ve kültürel uygulamalarının bitkide koçan oluşumuna etki ettiğini göstermektedir. Farklı araştırmalarda bitki başına koçan sayısının çevre koşullarından etkilendiği, birim alandaki bitki sıklığı ve azotlu gübre uygulamalarına göre önemli farkl1lık belirlenmiştir (Turgut, 2000; Sönmez ve ark., 2013; Thakur ve ark., 2015).

Çizelge 3. Şeker mısırında farklı uygulamaların ilk koçan yüksekliğine $(\mathrm{cm})$ ve bitki başına koçan sayısına (adet/bitki) etkisi

Table 3. Effect of different applications on first ear height $(\mathrm{cm})$ and ear number per plant (ear/plant) in sweet corn

\begin{tabular}{|c|c|c|c|c|c|c|}
\hline \multirow[t]{2}{*}{ Uygulamalar/Applications } & \multicolumn{2}{|c|}{ Y1llar/Years } & \multirow{2}{*}{$\begin{array}{l}\text { Ortalama/ } \\
\text { Mean }\end{array}$} & \multicolumn{2}{|c|}{ Y1llar/Years } & \multirow{2}{*}{$\begin{array}{l}\text { Ortalama/ } \\
\text { Mean }\end{array}$} \\
\hline & 2015 & 2016 & & 2015 & 2016 & \\
\hline Kontrol /Control & 34.27 & 39.37 & $36.82 \mathrm{~B}^{1}$ & 1.33 & 1.13 & $1.23 \mathrm{~B}$ \\
\hline Deniz yosunu /Seaweed & 41.80 & 44.27 & $43.04 \mathrm{~A}$ & 1.47 & 1.27 & $1.37 \mathrm{~B}$ \\
\hline $\begin{array}{l}\text { Azotlu gübre }+ \text { deniz yosunu/ } \\
\text { Fertizer with nitrogen }+ \text { Seaweed }\end{array}$ & 40.60 & 43.73 & $42.17 \mathrm{~A}$ & 1.53 & 1.50 & $1.52 \mathrm{~B}$ \\
\hline $\begin{array}{l}\text { Kat1 ve s1v1 deniz yosunu/ } \\
\text { Solid and liquit Seaweed }\end{array}$ & 40.50 & 43.20 & $41.85 \mathrm{~A}$ & 1.50 & 1.33 & $1.42 \mathrm{~B}$ \\
\hline $\begin{array}{l}\text { Ekim öncesi gül posas1/ } \\
\text { Application of rose pulp in presowing }\end{array}$ & 43.57 & 43.90 & $43.73 \mathrm{~A}$ & 1.47 & 1.43 & $1.45 \mathrm{~B}$ \\
\hline $\begin{array}{l}\text { Ekimle birlikte gül posas1 } \\
\text { Application of rose pulp with sowing }\end{array}$ & 42.10 & 43.10 & $42.60 \mathrm{~A}$ & 1.37 & 1.40 & $1.38 \mathrm{~B}$ \\
\hline $\begin{array}{l}\text { Azotlu gübre }+ \text { gül posas } 1 \\
\text { Fertizer with nitrogen }+ \text { Rose pulp }\end{array}$ & 41.73 & 42.97 & $42.35 \mathrm{~A}$ & 1.57 & 1.50 & $1.53 \mathrm{~B}$ \\
\hline $\begin{array}{l}10 \mathrm{~kg} \mathrm{da}^{-1} \text { azotlu gübre/ } \\
10 \mathrm{~kg} \mathrm{da}^{-1} \text { Fertizer with nitrogen }\end{array}$ & 42.83 & 43.23 & $43.03 \mathrm{~A}$ & 1.90 & 1.87 & $1.88 \mathrm{~A}$ \\
\hline $\begin{array}{l}20 \mathrm{~kg} \mathrm{da}^{-1} \text { azotlu gübre/ } \\
20 \mathrm{~kg} \mathrm{da}^{-1} \text { Fertizer with nitrogen }\end{array}$ & 42.63 & 43.37 & $43.00 \mathrm{~A}$ & 2.07 & 1.93 & $2.00 \mathrm{~A}$ \\
\hline \multirow[t]{2}{*}{ Ortalama/Mean } & $41.12 \mathrm{~B}^{1}$ & 43.02 A & & $1.58 \mathrm{~A}$ & $1.49 \mathrm{~B}$ & \\
\hline & \multicolumn{3}{|c|}{$\begin{array}{l}\text { Yıl/Year:4.852*; } \\
\text { Uygulama/Application:3.322**; } \\
\text { YılxUygulama/YearxApplication: } 1.404 ; \\
\text { CV: } \% 5.46\end{array}$} & \multicolumn{3}{|c|}{$\begin{array}{l}\text { Yll/Year:4.401*; } \\
\text { Uygulama/Application:14.299**; } \\
\text { YılxUygulama/YearxApplication: } \\
0.408 ; \text { CV: } \% 10.59\end{array}$} \\
\hline
\end{tabular}

*\%5 ve **\% 1 önemlidir. CV: Coefficient Variance ${ }^{1}$ Aynı sütunda ve aynı satırda farklı harfle verilen ortalamalar arasındaki fark önemlidir.

\subsection{Koçan çapı ve Koçan randımanı}

Koçan çapı, koçanın pazarlanma değerini arttıran önemli özelliklerden birisidir. Farklı uygulamaların koçan çapına etkisi önemli bulunmuştur (Çizelge 4). Araştırmada iki yıllık ortalamaya göre koçan çapı 40.13-45.60 mm arasında değişmiş, en düşük değer kontrol uygulamasında belirlenmiştir. Azotlu gübre ve organik madde uygulamaları koçan çapında artış meydana getirmiştir. Ancak, kontrol ile ekimle birlikte gül posası ve deniz yosunu uygulamaları istatistiksel olarak aynı grupta yer almıştır. Koçan çapı değeri denemenin birinci yılında 43.97 mm, 2. yılında ise $43.0 \mathrm{~mm}$ olarak belirlenmiş ve yıllar arasındaki farklılık önemli bulunmuştur. Koçan çapı, verimi etkileyen özelliklerden birisidir. Nitekim araştırmada genel ortalama olarak pazarlanabilir kavuzlu ve kavuzsuz koçan veriminde (Çizelge 5) ilk yıl daha yüksek değerler elde edilmiştir. Tane dolumu sırasında çevre faktörlerinin uygun olması koçan çapında olumlu yönde bir etki meydana getirmektedir (Aldrich ve ark., 1982).

Koçan çapı, koçan iriliğini dolayısıyla tane verimini belirlemekte ve pazar değerini arttırmaktadır. Araştırmalarda koçan çapının kalıtım derecesi düşük (Saleh ve ark., 2002) ve çevre faktörlerinin etkisinin daha fazla olduğu bildirilmiştir (Öktem ve Öktem, 2006; Eser, 2014). 
Alp (2000), tarafından yürütülen araştırmada, uygulanan azot dozlarının, koçan çapını ve dekara pazarlanabilir taze koçan verimini önemli derecede olumlu etkilediği bildirilmiştir. Denemede koçan çapı ve dekara taze koçan verimi için en yüksek değerler, $14 \mathrm{~kg} \mathrm{da}^{-1} \mathrm{~N}$ uygulamasından elde edilmiştir. Benzer sonuçlar farklı çalışmalarda belirlenmiş ve azot dozuna bağlı olarak koçan çapının arttığı bildirilmiştir (Turgut 2000; Altıparmak, 2001). Yine, koçan çapının çeşide ve yıllara göre değiştiği bildirilmiş ve Vega F1 çeşidinde ortalama koçan çap $147.10 \mathrm{~mm}$ olarak belirlenmiştir (Öktem ve Öktem, 2006). Karaman ekolojik şartlarında yapılan çalışmada çeşitlere göre koçan çapı önemli değişiklik göstermiş ve Vega F1 çeşidinde 44.65 mm olarak belirlenmiştir (Eser, 2014).

Kavuzlu koçan ağırlığının, kavuzsuz koçan ağırlığına oranlanması ile elde edilen koçan randımanı (\%) değerleri Çizelge 4'te gösterilmiştir. Araştırmada koçan randımanı yıllara ve uygulamalara bağlı olarak önemli değişiklik göstermiştir. İki yıllık ortalamalara göre en yüksek koçan randımanı $20 \mathrm{~kg} \mathrm{da}^{-1}$ uygulamasında (\% 74.78) belirlenmiş olmakla birlikte $10 \mathrm{~kg} \mathrm{da}^{-1}(\%$ 73.12) ve organik materyale azotlu gübre ilave edilmiş uygulamalardan (\% 71.20 ve \% 70.93) elde edilmiştir. Bu sonuçlar azotun koçan randımanı üzerine önemli etkisinin olduğunu göstermektedir. En düşük koçan randımanı kontrol uygulamasında (\% 61.17) belirlenmiş ancak, deniz yosunu (\% 62.98), katı ve sıvı deniz yosunu (\% 64.18) ile ekimle birlikte gül posası (\% 62.65) uygulamaları arasındaki fark önemli bulunmamıştır. Bu sonuçlar organik materyale azot ilave edilmediği uygulamalarda kavuz oranının daha fazla olduğu anlamına gelmektedir. De Grazia ve ark. (2003), tarafından yapılan çalışmada en yüksek kavuz oranı (\% 30.95) azot uygulanmayan parsellerden elde edilmiş ve azotlu gübre uygulaması kavuz oranını azaltmıştır.

Araştırmada genel ortalama olarak 2. yıl koçan randımanı önemli seviyede azalmış (\%66.39) olmasına rağmen, dekara $10 \mathrm{~kg}$ (\% 74.10) ve $20 \mathrm{~kg}$ (\% 76.20) azot uygulaması artmıştır. Bu durum yıl x azot interaksiyonunun önemli çıkmasina neden olmuştur.

Koçanın ağırlığında kavuz miktarı diğer bir ifade ile koçan randımanı, elde edilen ürünün niteliği açısından önemlidir. Koçan randımanı üzerinde yapılan araştırmalarda çeşidin yanında farklı uygulamalarının etkisi de incelenmiştir. Tuncay ve ark. (2005), tarafından yapılan çalışmada koçan randımanı üzerine yetiştirme döneminin etkisinin önemli olmadığı, ancak çeşitlere göre önemli farklılık gösterdiği (\% 63.55-80.83) belirlenmiştir. Yine, çeşidin yanında lokasyonlara bağlı olarak koçan randımanın değiştiği tespit edilmiş̧ir (Eşiyok ve ark., 2004). Tatlı mısırda ekim/dikim döneminin ve tohum ekimi ile fide dikim şeklinin koçan randımanı üzerine etkisi istatistiki olarak önemsiz bulunmuştur (Eşiyok ve Bozokalfa, 2005). Araştırmada yetiştirme dönemindeki iklim koşulları ve uygulamaların koçanın kavuz miktarına değiştirebildiği belirlenmiştir.

Çizelge 4. Şeker mısırında farklı uygulamaların koçan çapına (mm) ve koçan randımanına (\%) etkisi

Table 4. Effect of different applications on ear diameter ( $\mathrm{mm}$ ) and husk ratio (\%) in sweet corn

\begin{tabular}{|c|c|c|c|c|c|c|}
\hline \multirow[t]{2}{*}{ Uygulamalar/Applications } & \multicolumn{2}{|c|}{ Y1llar/Years } & \multirow{2}{*}{$\begin{array}{l}\text { Ortalama/ } \\
\text { Mean }\end{array}$} & \multicolumn{2}{|c|}{ Yillar/Years } & \multirow{2}{*}{$\begin{array}{l}\text { Ortalama/ } \\
\text { Mean }\end{array}$} \\
\hline & 2015 & 2016 & & 2015 & 2016 & \\
\hline Kontrol /Control & 41.17 & 39.10 & $40.13 \mathrm{C}^{1}$ & $64.83 b^{1}$ & $57.50 \mathrm{e}^{1}$ & $61.17 \mathrm{D}^{1}$ \\
\hline Deniz yosunu/Seaweed & 43.20 & 40.53 & $41.87 \mathrm{BC}$ & $68.23 \mathrm{ab}$ & $57.73 \mathrm{e}$ & $62.98 \mathrm{CD}$ \\
\hline $\begin{array}{l}\text { Azotlu gübre }+ \text { deniz yosunu/ } \\
\text { Fertizer with nitrogen }+ \text { Seaweed }\end{array}$ & 43.83 & 43.83 & $43.83 \mathrm{AB}$ & $72.63 \mathrm{a}$ & $69.77 \mathrm{bc}$ & $71.20 \mathrm{AB}$ \\
\hline $\begin{array}{l}\text { Kat1 ve s1v1 deniz yosunu/ } \\
\text { Solid and liquit Seaweed }\end{array}$ & 43.57 & 41.97 & $42.77 \mathrm{BC}$ & $65.83 \mathrm{~b}$ & $62.53 \mathrm{de}$ & $64.18 \mathrm{CD}$ \\
\hline $\begin{array}{l}\text { Ekim öncesi gül posas1/ } \\
\text { Application of rose pulp in presowing }\end{array}$ & 45.40 & 44.77 & $45.08 \mathrm{~A}$ & $68.20 \mathrm{ab}$ & $67.17 \mathrm{~cd}$ & $67.68 \mathrm{BC}$ \\
\hline $\begin{array}{l}\text { Ekimle birlikte gül posas } 1 \\
\text { Application of rose pulp with sowing }\end{array}$ & 42.97 & 40.67 & $41.82 \mathrm{BC}$ & $63.60 \mathrm{~b}$ & $61.70 \mathrm{e}$ & $62.65 \mathrm{D}$ \\
\hline $\begin{array}{l}\text { Azotlu gübre }+ \text { gül posas } 1 \\
\text { Fertizer with nitrogen }+ \text { Rose pulp }\end{array}$ & 45.10 & 44.73 & $44.92 \mathrm{~A}$ & $71.10 \mathrm{a}$ & $70.77 \mathrm{bc}$ & $70.93 \mathrm{AB}$ \\
\hline $\begin{array}{l}10 \mathrm{~kg} \mathrm{da}^{-1} \text { azotlu gübre/ } \\
10 \mathrm{~kg} \mathrm{da}^{-1} \text { Fertizer with nitrogen }\end{array}$ & 45.20 & 45.47 & $45.33 \mathrm{~A}$ & $72.13 \mathrm{a}$ & $74.10 \mathrm{ab}$ & $73.12 \mathrm{~A}$ \\
\hline $\begin{array}{l}20 \mathrm{~kg} \mathrm{da}^{-1} \text { azotlu gübre/ } \\
20 \mathrm{~kg} \mathrm{da}^{-1} \text { Fertizer with nitrogen }\end{array}$ & 45.30 & 45.90 & $45.60 \mathrm{~A}$ & $73.37 \mathrm{a}$ & $76.20 \mathrm{a}$ & $74.78 \mathrm{~A}$ \\
\hline Ortalama/Mean & $43.97 B^{1}$ & $43.00 \mathrm{~A}$ & & $68.88 \mathrm{~A}^{1}$ & $66.39 \mathrm{~B}$ & \\
\hline & $\begin{array}{l}\text { Yil/Year } \\
\text { Uygulan } \\
\text { YılxUyg } \\
\text { CV:\% } 3 .\end{array}$ & $\begin{array}{l}73 * \\
\text { pplicati } \\
\text { na/Year }\end{array}$ & $\begin{array}{l}34 * * ; \\
\text { cation:0.90; }\end{array}$ & $\begin{array}{l}\text { Yıl/Year:9. } \\
\text { Uygulama/ } \\
\text { YılxUygula } \\
\text { CV :\%4.3 }\end{array}$ & $\begin{array}{l}\text { lication: } 18 . \\
\text { YearxAppli }\end{array}$ & *; $3.186^{* *}$ \\
\hline
\end{tabular}

*\%5 ve ** \% 1 önemlidir. CV: Coefficient Variance ${ }^{1}$ Aynı sütunda ve aynı satırda farklı harfle verilen ortalamalar arasındaki fark önemlidir. 


\subsection{Pazarlanabilir Taze Koçan Verimi ve Pazarlanabilir Kavuzsuz Koçan Verimi}

Pazarlanabilir özellikteki koçan ağırlığından hesaplanan dekara kavuzlu koçan verimi üzerine uygulamaların etkisi önemli bulunmuştur (Çizelge 5). Ayrıca, uygulamalardan elde edilen verim değerleri yıllara göre farklılık göstermiş ve uygulama x yıl interaksiyonu önemli çıkmıştır. Her iki yılda kontrol uygulamasından en düşük değerler elde edilmiştir. Organik materyal (gül posası ve deniz yosunu) ve azotlu gübre uygulamaları kavuzlu koçan verimini arttırmıştır. Pazarlanabilir kavuzlu koçan verimi denemenin ilk yılında 2924.89-5014.25 kg da ${ }^{-1}$; ikinci yılında ise $1879.17-596.82 \mathrm{~kg} \mathrm{da}^{-1}$ arasında belirlenmiştir. İki yıllık ortalamalara göre en yüksek pazarlanabilir kavuzlu koçan verimi (5491.54 $\mathrm{kg} \mathrm{da}^{-1}$ ) $20 \mathrm{~kg} \mathrm{da}^{-1}$ azotlu gübre uygulamasında belirlenmiş, ancak $10 \mathrm{~kg} \mathrm{da}^{-1}$ uygulaması (5051.47 $\mathrm{kg} \mathrm{da}^{-1}$ ) ile arasındaki fark önemli bulunmamıştır. $10 \mathrm{~kg} \mathrm{da}^{-1} \mathrm{ve} 20 \mathrm{~kg} \mathrm{da}^{-1}$ uygulamalarında, azotla zenginleştirilmiş deniz yosunu (3955.00 $\left.\mathrm{kg} \mathrm{da}^{-1}\right)$ ve gül posası $\left(3942.77 \mathrm{~kg} \mathrm{da}^{-1}\right)$ uygulamalarından da daha yüksek değerler elde edilmiştir (Çizelge 5).

Kavuzsuz koçan verimine ait ortalamalar Çizelge 5'te verilmiştir. Uygulamalara göre, pazarlanabilir kavuzsuz koçan verimi 1. yılda $1898.40-3678.0 \mathrm{~kg} \mathrm{da}^{-1}$, ikinci yllda $1079.42-4547.52 \mathrm{~kg} \mathrm{da}^{-1}$ ve iki yıllık ortalamada ise, 1488.91-4112.76 kg da ${ }^{-1}$ arasında değişmiştir. Organik materyal ve azotlu gübre uygulamalarında pazarlanabilir kavuzsuz koçan verimi artmıştır. En düşük değerler kontrol uygulamasında, en yüksek değerler ise $20 \mathrm{~kg} \mathrm{da}^{-1} \mathrm{~N}$ uygulamasında belirlenmiş ve diğer uygulamalardan istatistiksel olarak farklı bulunmuştur. Kavuzlu koçan veriminde 10 ve $20 \mathrm{~kg} \mathrm{da}^{-1}$ azot uygulamalarında istatistiksel olarak önemli fark bulunmaz iken, pazarlanabilir kavuzsuz koçan veriminde bu fark önemli çıkmıştır. Bu sonuçlar koçan kavuzlarının düşük azot dozlarında daha fazla olduğunu göstermektedir (Çizelge 5). Organik materyale ilave azot verildiğinde pazarlanabilir kavuzsuz koçan verimi de artmıştır. Toprakta bulunan azot miktarı artıkça, bitki gelişmesi ve buna bağlı olarak fotosentez de artmakta, koçana daha fazla besin maddesi taşındığından verim olumlu yönde etkilenmektedir.

Denemenin ilk yılında pazarlanabilir kavuzlu ve kavuzsuz koçan verimi daha fazla olmasına rağmen, yıllar arasındaki bu farklılık önemli değildir. Ancak her iki özellikte de yıl x uygulama interaksiyonu önemlidir (Çizelge 5). Bu durum denemenin kurulduğu yıllarda aylara göre sıcaklık ve yağışın farklı olması yanında, toprak özelliklerinden de kaynaklandığı düşünülmektedir.

Çizelge 5. Şeker mısırında farklı uygulamaların pazarlanabilir kavuzlu ve kavuzsuz koçan verimine $\left(\mathrm{kg} \mathrm{da}^{-1}\right)$ etkisi Table 5. Effect of different applications on marketable husked ear yield $\left(\mathrm{kg} \mathrm{da}^{-1}\right)$ and marketable huskless ear yield

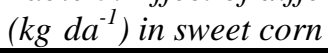

\begin{tabular}{|c|c|c|c|c|c|c|c|}
\hline \multirow[t]{2}{*}{ Uygulamalar/Applications } & \multicolumn{2}{|c|}{ Yillar/Years } & \multirow{2}{*}{\multicolumn{2}{|c|}{$\begin{array}{l}\text { Ortalama/ } \\
\text { Mean }\end{array}$}} & \multicolumn{2}{|c|}{ Y1llar/Years } & \multirow{2}{*}{$\begin{array}{l}\text { Ortalama/ } \\
\text { Mean }\end{array}$} \\
\hline & 2015 & 2016 & & & 2015 & 2016 & \\
\hline Kontrol /Control & $2924.89 \mathrm{~d}^{1}$ & $1879.17 \mathrm{e}^{1}$ & 2402 & $03 \mathrm{E}^{1}$ & $1898.40 \mathrm{e}$ & $1079.42 \mathrm{e}$ & $1488.91 \mathrm{E}$ \\
\hline Deniz yosunu /Seaweed & $3076.21 \mathrm{~d}$ & $2666.67 \mathrm{~d}$ & 2871 & $14 \mathrm{DE}$ & $2110.25 \mathrm{de}$ & $1540.30 \mathrm{~d}$ & $1825.28 \mathrm{DE}$ \\
\hline $\begin{array}{l}\text { Azotlu gübre }+ \text { deniz yosunu/ } \\
\text { Fertizer with nitrogen }+ \text { Seaweed }\end{array}$ & $3950.52 \mathrm{~b}$ & $3959.47 \mathrm{c}$ & 395 & $00 \mathrm{~B}$ & $2875.08 \mathrm{~b}$ & $2751.70 \mathrm{c}$ & $2813.39 \mathrm{C}$ \\
\hline $\begin{array}{l}\text { Kat1 ve s1v1 deniz yosunu/ } \\
\text { Solid and liquit Seaweed }\end{array}$ & $3733.45 \mathrm{bc}$ & $2811.04 \mathrm{~d}$ & 3272 & $5 \mathrm{CD}$ & $2435.10 \mathrm{~cd}$ & $1759.07 \mathrm{~d}$ & 2097.09 D \\
\hline $\begin{array}{l}\text { Ekim öncesi gül posas1/ } \\
\text { Application of rose pulp in } \\
\text { presowing }\end{array}$ & $3707.65 \mathrm{bc}$ & $3667.48 \mathrm{c}$ & 3687 & $57 \mathrm{BC}$ & $2547.17 \mathrm{bc}$ & $2464.46 \mathrm{c}$ & $2505.82 \mathrm{C}$ \\
\hline $\begin{array}{l}\text { Ekimle birlikte gül posas } 1 \\
\text { Application of rose pulp with } \\
\text { sowing }\end{array}$ & $3352.14 \mathrm{~cd}$ & $3101.81 \mathrm{~d}$ & 3226 & $8 \mathrm{CD}$ & $2129.37 \mathrm{de}$ & $1914.72 \mathrm{~d}$ & $2022.05 \mathrm{D}$ \\
\hline $\begin{array}{l}\text { Azotlu gübre }+ \text { gül posas } 1 \\
\text { Fertizer with nitrogen }+ \text { Rose pulp }\end{array}$ & $3904.22 \mathrm{~b}$ & $3981.32 \mathrm{c}$ & 3942 & $77 \mathrm{~B}$ & $2777.12 \mathrm{bc}$ & $2818.88 \mathrm{c}$ & $2798.00 \mathrm{C}$ \\
\hline $\begin{array}{l}10 \mathrm{~kg} \mathrm{da}^{-1} \text { azotlu gübre/ } \\
10 \mathrm{~kg} \mathrm{da}^{-1} \text { Fertizer with nitrogen }\end{array}$ & $4856.29 \mathrm{a}$ & $5246.64 \mathrm{~b}$ & 5051 & $47 \mathrm{~A}$ & $3504.16 \mathrm{a}$ & $3886.22 \mathrm{~b}$ & $3695.19 \mathrm{~B}$ \\
\hline $\begin{array}{l}20 \mathrm{~kg} \mathrm{da}^{-1} \text { azotlu gübre/ } \\
20 \mathrm{~kg} \mathrm{da}^{-1} \text { Fertizer with nitrogen }\end{array}$ & $5014.25 \mathrm{a}$ & $5968.82 \mathrm{a}$ & 5491 & $54 \mathrm{~A}$ & $3678.00 \mathrm{a}$ & $4547.52 \mathrm{a}$ & $4112.76 \mathrm{~A}$ \\
\hline Ortalama/Mean & 3835.51 & 3698.05 & & & 2661.63 & 2529.14 & \\
\hline & $\begin{array}{l}\text { Yıl/Year: } 2.4 \\
\text { Uygulama/ } \\
\text { YılxUygula } \\
* * ; \text { CV \%: } 8\end{array}$ & $\begin{array}{l}\text { plication:57 } \\
\text { /YearxAppl } \\
5\end{array}$ & $\begin{array}{l}0 * * ; \\
0 * \text { tion: }\end{array}$ & 5.486 & $\begin{array}{r}\text { Uygul } \\
\text { YlixUygu }\end{array}$ & $\begin{array}{l}\text { Il/Year: } 4 . \\
\text { /Applicatic } \\
\text { a/YearxAp } \\
; \text { CV } \%: 9\end{array}$ & $\begin{array}{l}7.18 * * ; \\
\text { ation: } 7.29\end{array}$ \\
\hline
\end{tabular}

\footnotetext{
*\%5 ve ** \% 1 önemlidir. CV: Coefficient Variance. ${ }^{1}$ Aynı sütunda ve aynı satırda farklı harfle verilen ortalamalar arasındaki fark önemlidir.
} 
Şeker mısırında koçanların satışı kavuzlu bir şekilde yapıldığından kavuzlu koçan verimi, pazarlama ve tüketici açısından da pazarlanabilir kavuzsuz koçan verimi dikkate alınabilecek bir özelliktir. Şeker mısırı üzerinde yapılan çalışmalarda koçan veriminin çeşide, ekolojik koşullara, uygulanan kültürel işlemlere göre değişebildiği bildirilmiştir. Nitekim, De Grazia et al. (2003), şeker mısırında azotlu ( N0=N1=10 kg da ${ }^{-1}, \mathrm{~N} 2=20 \mathrm{~kg} \mathrm{da}^{-1}$ ) gübre uygulamalarının etkisinin önemli, fosforlu gübrelemenin önemli bir etkisinin olmadığını tespit etmişlerdir. Araştırıcılar kavuzlu (1834 kg da ${ }^{-1}$ ve $\left.2209.2 \mathrm{~kg} \mathrm{da}^{-1}\right)$ ve kavuzsuz $\left(1331.3 \mathrm{~kg} \mathrm{da}^{-1}\right.$ ve $\left.1575.0 \mathrm{~kg} \mathrm{da}^{-1}\right)$ koçan veriminin $10-20 \mathrm{~kg} \mathrm{da}^{-1} \mathrm{~N}$ uygulamaları arasında fark olmadığını ortaya koymuşlardır. Can ve Akman (2014) tarafindan yapılan çalışmada, azot dozu artışına paralel olarak taze koçan verimi de artmıştır. En yüksek taze koçan verimi $21 \mathrm{~kg} \mathrm{da}^{-1} \mathrm{~N}$ dozunda $\left(1652.0 \mathrm{~kg} \mathrm{da}^{-1}\right)$ belirlenmiş, ancak $14 \mathrm{~kg} \mathrm{da}^{-1} \mathrm{~N}$ uygulamasından $\left(1373.7 \mathrm{~kg} \mathrm{da}^{-1}\right)$ elde edilen verim arasında önemli bir fark bulunmamıştır. Ayrıca, en düşük pazarlanabilir taze koçan verimi ise, azot uygulanmayan parsellerde $\left(702.0 \mathrm{~kg} \mathrm{da}^{-1}\right)$ tespit edilmiştir. Azot dozuna bağlı olarak koçan veriminin arttığ farklı araştırıcılar tarafindan da bildirilmiştir (Turgut, 2000; Altıparmak, 2001).

Koçan veriminin çeşide (Öktem ve Öktem, 2006; Eser, 2014; Stansluos ve ark., 2020), ekim zamanına (Voicu ve ark., 2012; Dekhane ve Dumbre, 2017; Burcu ve Akgün, 2018; Kaymak ve Ürüşan, 2020), bitki siklığına (Turgut, 2000; Burcu ve Akgün, 2018), yıllara (Sönmez ve ark., 2013) göre önemli farklılık gösterdiği belirlenmiştir. Eser (2014) ve Öktem ve Öktem (2006), tarafından yapılan çalışmada en yüksek taze koçan verimi Vega F1 çeşidinde belirlenmiştir (sırasıyla $1523.33 \mathrm{~kg} \mathrm{da}^{-1} \mathrm{ve} 1637 \mathrm{~kg} \mathrm{da}^{-1}$ ). Yapılan araştırma sonuçları incelendiğinde, aynı çeşitlerin farklı ekolojik koşullarında ve uygulamalarda verimi değişebilmektedir. Bu sonuçlar koçan veriminin çevre şartlarından etkilendiğini göstermektedir.

Araştırmada Vega F1 çeşidinde deniz yosunu ve gül posası uygulamaları bitki gelişmesine olumlu katkı sağlamıştır. Deniz yosununun gübre olarak kullanıldığında, bitki gelişmesi üzerine olumlu etkisinin olduğu, farklı bitki türlerinde belirlenmiştir (Hong ve ark., 1995; Hong et al., 2007; Nabila et al., 2007). Şeker mısırında en yüksek taze koçan veriminin $10 \mathrm{~kg} \mathrm{~N} / \mathrm{ha}+$ Azotobacter uygulamasında elde edildiği bildirilmiştir (Akgün ve Siyah, 2015). Yine, mısırda N biyogübre uygulamalarının (Azotobacter, Nitroxin ve Supernitroplus) sap ağırlığı, yaprak ağırlığı, koçan ağırlığı ve biyomas verimi üzerine önemli etkisi olduğu tespit edilmiştir (Farnia ve Ashjardi, 2015).

Gül posasının bitki gelişimini olumlu yönde etkilediğinden tarımsal amaçlı doğrudan veya zenginleştirilerek kullanılabileceği bildirilmiştir (Erdal ve Aydemir, 2003). Yapılan araştırmalarda gül posasının besin içeriğinin kaliteli olduğu belirlenmiştir.

\section{Sonuç}

Araştırmada deniz yosunu ve gül posası uygulamalarının Vega F1 çeşidinde incelenen özellikler üzerine etkisi olumlu olmuştur. Ancak en yüksek pazarlanabilir kavuzlu ve kavuzsuz koçan verimi $20 \mathrm{~kg} \mathrm{da}^{-1} \mathrm{~N}$ uygulamasından elde edilmiştir. Organik materyal olarak deniz yosunu ve gül posası uygulandığında Vega F1 çeşidinden yüksek verim elde edebilmek için ilave azotun verilmesi gerektiği ortaya konulmuştur. Isparta ilinde yılda yaklaşık 30 bin tona yakın gül posası üretildiği düşünüldüğünde, bu organik atığın tarımsal üretime kazandırılması, toprakların organik madde içeriğine katkı sağlayabileceği gibi, kullanılan azotlu gübre dozunu da azaltabilecektir.

\section{Kaynaklar}

Akgün, İ., Siyah, C., 2015. Effects of bio-fertilizer (Azotobacter spp., Mycorrhiza spp., Bacillus spp.) and different nitrogen levels on fresh ear yield and yield components of sweet corn (Zea mays saccharata Sturt.). In Proceedings of the 7th Congress on Plant Protection" Integrated Plant Protection-a Knowledge-Based Step Towards Sustainable Agriculture, Forestry and Landscape Architecture". November 24-28, Zlatibor, Serbia (pp. 195-199).

Akgün, İ., Burcu, Y., Karaman, R., Kaya, M., 2017. Isparta koşullarında farklı ekim zamanı ve bitki sıklığının şeker mısırında (Zea mays saccharata Sturt.) taze koçan ağırlığı ve bazı tarımsal özelliklere etkisi. Tarla Bitkileri Merkez Araştırma Enstitüsü Dergisi, 26(1):23-30. do1: 10.19113/sdufbed.70486

Aldrich, S.R., Scott, W.D., Leng, E.R, 1982. Modern Corn Production. A and L. Publications, Station A, Box F,Champaigne, Illions, 61820

Alp, R., 2000. Şeker mısırında (Zea mays saccharata Sturt.) azot ve potasyumun verim ve verim unsurlarına etkileri. Yüksek Lisans Tezi. Gaziosmanpaşa Üniversitesi Fen Bilimleri Enstitüsü, 47 s, Tokat.

Altıparmak, S., 2001. Şeker mısırda farklı azot dozlarının verim ve verim öğelerine etkisi. Yüksek Lisans Tezi. Ankara Üniversitesi Fen Bilimleri Enstitüsü, 50 s, Ankara.

Anonim, 2010. Tarımsal değerleri ölçme denemeleri teknik talimatı (Mısır). Tarım ve Köyişleri Bakanlığı Tarımsal Üretim ve Geliştirme Genel Müdürlüğü Tohumluk Tescil ve Sertifikasyon Merkezi Müdürlüğü. https://www.tarimorman.gov.tr/BUGEM/TTSM/Belgeler/Tescil/Teknik\%20Talimatlar/S\% 
$\mathrm{C} 4 \% \mathrm{~B} 1 \mathrm{cak} \% 20 \% \mathrm{C} 4 \% \mathrm{~B} 0 \mathrm{klim} \% 20 \mathrm{Tah} \% \mathrm{C} 4 \% \mathrm{~B} 11 \mathrm{lar} \% \mathrm{C} 4 \% \mathrm{~B} 1 / \mathrm{m} \% \mathrm{C} 4 \% \mathrm{~B} 1 \mathrm{~s} \% \mathrm{C} 4 \% \mathrm{~B} 1 \mathrm{r}$.pdf $\quad$ (Erişim $\quad$ tarihi 03.03.2021).

Arslan, Z.F., Williams, M.M., 2015. Türkiye ve Dünya Tatlı Mısır Üretiminde Sorunlar. Gıda Tarım ve Hayvancılık Bakanlığı Dergisi, 224, 64-68.

Baydar, H., Erbaş, S., Şanlı, A., Kara, N., 2020. Yağ gülünün damıtma atı̆̆ı olan posanın element içeriği ve değerlendirme olanakları üzerine bir araştırma. Türk Bilim ve Mühendislik Dergisi, 1(1): 1-4.

Burcu, Y., Akgün, İ., 2018. Isparta koşullarında farklı ekim zamanı ve bitki sıklığının şeker mısırında (Zea mays saccharata Sturt.) taze koçan verimi ve kalite özellikleri üzerine etkisi. Süleyman Demirel Üniversitesi Fen Bilimleri Enstitüsü Dergisi, 22(2): 679-684. do1: 10.19113/sdufbed.70486

Can, M., Akman, Z., 2014. Uşak ekolojik şartlarında farklı azot dozlarının şeker mısırın (Zea mays saccharata Sturt.) verim ve kalite özelliklerine etkisi. Ziraat Fakültesi Dergisi, 9(2): 93-101.

De Grazia, J., Tittonell, P.A., Germinara, D., Chiesa, A., 2003. Phosphorus and nitrogen fertilisation in sweet corn (Zea mays L. var. saccharata Bailey). Spanish Journal of Agricultural Research, 1(2): 103-107.

Dekhane, S.S., Dumbre, R.B., 2017. Influence of different sowing dates on plant growth and yield of hybrid sweet corns. Advance Research Journal of Crop Improvement, 8(2):191-194. doi: 10.15740 / has / arjci / 8.2 / 191-194

Dickerson, W. G. (1996). Home and market sweet corn production. New Mexico State University. http://www.cahe.nmsu.edu/pubs/_h/h-223.html. (Erişim tarihi:20 Şubat 2021).

Erdal, İ., Aydemir, O., 2003. Gül posasının doğrudan ve zenginleştirilmiş formunun tarımda kullanılabilme olanakları. Süleyman Demirel Üniversitesi Fen Bilimleri Enstitüsü Dergisi, 7(1): 20-26.

Eser, C., 2014. Orta Anadolu koşullarında seker mısır (Zea mays L. saccharata Sturt.) çeşitlerinin taze koçan ve tane verimleri ile önemli agronomik özelliklerinin belirlenmesi. Yüksek Lisans Tezi. Selçuk Üniversitesi Fen Bilimleri Enstitüsü, $90 \mathrm{~s}$, Konya.

Eşiyok, D., Bozokalfa, M.K., Uğur, A., 2004. Farklı lokasyonlarda yetiştirilen şeker mısır (Zea mays saccharata Sturt.) çeşitlerinin verim kalite ve teknolojik özelliklerinin belirlenmesi. Ege Üniversitesi Ziraat Fakültesi Dergisi, 41(1):1-9

Eşiyok, D., Bozokalfa, M.K., 2005. Ekim ve dikim zamanlarının tatlı mısırda (Zea mays L. var. saccharata) verim ve koçanın bazı agronomik karakterleri üzerine etkisi. Ege Üniversitesi Ziraat Fakültesi Dergisi, 42(1): 35-46.

FAO, 2020. The Food and Agriculture Organization. Food and Agriculture Data. http://www.fao.org/ faostat/en/\#home (Erişim Tarihi: 1 Aralık 2020).

Farnia, A., Ashjardi, V.K., 2015. Effect of nitrogen biofertilizers on yield and yield components of different maize (Zea mays L.) cultivars. International Journal of Life Sciences, 9(5): 117-121. do1: dx.doi.org/10.3126/ijls.v9i5.12711

Giskin, J., Etran, Y., 1986. Planting date and foliar fertilization of corn grown for silage and grain under limited moisture. Argonomy Journal, 78: 475-476

Hanna, H.Y., Story, R.N., 1992. Yield and super swet corn as affected by $\mathrm{n}$ application timing plant densty, tiller removal and insecticides. Florida State Horticultural Society, 105: 343-344.

Hong, Y.P., Chen, C.C., Cheng, H.L., Lin, C.H., 1995. Analysis of auxin and cytokinin activity of commercial aqueous seaweed extract. Gartenbauwissenschaft (Germany).

Hong, S.D., Schepers, J.S., Francis, D.D., Schlemmer, M.R., 2007. Comparison of ground- based remote sensors for evaluation of corn biomass affected by nitrogen stress. Communications in Soil Science and Plant Analysis, 38(15-16): 2209-2226. do1: 10.1080/00103620701549157

İdikut, L., Kara S.N., 2013. Tane ürünü için yetiştirilen ikinci ürün mısır çeşitlerinin bazı verim öğeleri ile tane nişasta oranlarının belirlenmesi. KSÜ Doğa Bilimleri Dergisi, 16(1): 8-15.

Kaymak, H.Ç., Ürüşan, A.H., 2020. Performance of some sweet corn (Zea mays L. var. saccharata) cultivars in high altitude conditions. Atatürk Üniversitesi Ziraat Fakültesi Dergisi, 51(3): 288-296. doi: 10.17097/ataunizfd.704808

Keerthi, P., Prabhakara Reddy, G., Sunitha, N., 2017. Effect of Sowing Time on Growth and Yield of Sweet Corn Cultivars. Current Microbiology and Applied Sciences, 6(4): 777-782.

Nabila, M., Zaki, M.S., Karima, M. EL-Din, G., 2007. Growth and yield of some wheat cultivars irrigated with saline water in newly cultivated land as affected by biofertilization. Journal of Applied Science Research, 3:1121-1126.

Öktem, A., Öktem, A.G., 2006. Bazı şeker misır (Zea mays saccharata Sturt) genotiplerinin Harran Ovas1 koşullarında verim karakteristiklerinin belirlenmesi. Uludağ Üniversitesi Ziraat Fakültesi Dergisi, 20(1): 33-46.

Özata, E, Geçit, H.H., İkincikarakaya S.Ü., 2016. Orta Karadeniz ekolojik koşullarında şeker mısırda (Zea mays saccharata Sturt.) değişik ekim sıklıkları ve azot dozlarının verim öğelerine etkisi. Tarla Bitkileri Merkez Araştırma Enstitüsü Dergisi, 25(1): 74- 80. do1: 10.21566/tarbitderg.280206

Park, K.Y., Kang, Y.K., Park, S.U., Moon, H.G,. 1989. Effect of planting density and tiller removal on growth and yield of sweet corn hybrids. Korean Journal Of Crop Science, 34(2):192-197. 
Saleh, G.B., Alawi, S.A.S., Panjaitan, K., 2002. Performance, correlation and heritability studies on selected sweet corn synthetic populations. Pakistan Journal of Biological Sciences, 5(3): 251-254.

Sevov, A., 2017. Quality parameters of sweet corn grain. Agricultural Sciences/Agrarni Nauki, 9(21): 65-70. do1: 10.22620/agrisci.2017.21.010

Sharma, T.R. Adamu, I.M., 1984. The effect of plant population on the yield and yield attributing charecters in maize (Zea mays L.). Zeitschrift für Acker-und Pflanzenbau, 153(4): 315-318.

Sönmez, K., Alan, Ö., Kınacı, E., Kınacı, G., Kutlu, İ., Başçiftçi, Z.B., Evrenosoğlu, Y., 2013. Bazı şeker mısır çeşitlerinin (Zea mays saccharata Sturt) bitki, koçan ve verim özellikleri. Ziraat Fakültesi Dergisi, 8(1): 28-40.

Stanslous, A.A.L., Öztürk, A., Kodaz, S., 2020. Agronomic performance of different sweet corn varieties in the highest plain of turkey: quality characteristics. Atatürk Üniversitesi Ziraat Fakültesi Dergisi, 51(3): 249-257. doi: 10.17097/ataunizfd.680520

Thakur, A.K., Thakur, D.S., Patel, R.K., Pradhan, A., Kumar, P., 2015. Effect of different plant geometry and nitrogen levels, inrelation to growth characters, yield and economics on sweet corn (Zea mays sachharata L.) at bastar plateau zone. The Bioscan, 10(3): 1223-1226.

Tosun, İ., Günay, A., Gönüllü, M.T., 2003. Gül posasından biyogaz üretimi ve çevresel önemi. Katı Atık ve Çevre, 52: $1-18$.

Tuncay, Ö., Bozokalfa, M.K., Eşiyok, D., 2005. Ana ürün ve ikinci ürün olarak yetiştirilen bazı tatlı mısır çeşitlerinde koçanın agronomik ve teknolojik özelliklerinin belirlenmesi. Ege Üniversitesi Ziraat Fakültesi Dergisi, 42(1): 47-58.

Turgut, İ., 2000. Bursa koşullarında yetiştirilen şeker mısırında (Zea mays saccharata Sturt.) bitki sıklığının ve azot dozlarının taze koçan verimi ile verim öğeleri üzerine etkisi. Turkish Journal of Agriculture and Forestry, 24(3): 341- 347.

Turgut, İ., Balcı, A., 2002. Bursa koşullarında değişik ekim zamanlarının şeker mısırı (Zea mays L. var. saccharata Sturt.) çeşitlerinin taze koçan verimi ile verim öğeleri üzerine etkileri. Uludağ Üniversitesi Ziraat Fakültesi Dergisi, 16(2):79-91

USDA, 1992. United States Standards for Grades of Sweet Corn. Available at https://www.ams.usda.gov/gradesstandards/sweet-corn-grades-and-standards (Erişim tarihi: 15 Şubat 2021)

Voicu, A. M., Ciofu, R., Ivaşcu, A., Enescu, T. D., 2012. Influence Of Sowing Time And Growing Area Of Productıve Potential Of Sweet Corn Hybrıds. Academy Of Romanian Scientists, 1(1): 122-130.

Walter- Shea, E. A., Norman, J. M., Blad, B. L., Robinson, B. F., 1991. Leaf reflectance and transmittance in soybean and corn. Agronomy Journal, 83(3): 631-636.

Welbaum, G.E., 2015. Family Poaceae. Vegetable production and practices, 248-266. 